\title{
Inhibition of carbachol stimulated acid secretion by interleukin $1 \beta$ in rabbit parietal cells requires protein kinase $\mathrm{C}$
}

\author{
I L P Beales, J Calam
}

\begin{abstract}

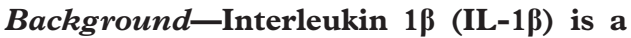
potent inhibitor of gastric acid secretion. Regulatory actions at several levels have previously been demonstrated, including direct inhibition of parietal cell acid secretion. Although IL-1 $\beta$ may activate several intracellular signalling pathways, the mechanisms responsible for inhibition of carbachol stimulated acid secretion have not been determined.

Aims-To investigate the roles of protein kinase $\mathrm{C}$ (PKC) and the sphingomyelinase signalling pathways in the regulation of acid secretion by IL-1ß.
\end{abstract}

Methods-Rabbit parietal cells were obtained by collagenase-EDTA digestion and centrifugal elutriation. Acid secretion stimulated by carbachol and A23187 (to mimic elevations in intracellular calcium) was assessed by ${ }^{14} \mathrm{C}$ aminopyrine uptake in response to IL-1 $\beta$, PKC, and sphingomyelinase manipulation.

Results-IL-1 $\beta$ inhibited carbachol and A23187 stimulated acid secretion in a dose dependent manner. The inhibitory actions were completely reversed by each of three different PKC inhibitors, staurosporine, H-7, and chelerythrine, as well as by PKC depletion with high dose phorbol ester pretreatment. IL-1 $\beta$ did not downregulate parietal cell muscarinic receptor. IL-1 $\beta$ significantly increased membrane PKC activity. Activation of the sphingomyelinase/ceramide pathway had no effect on basal or stimulated acid secretion. The inhibitory action of IL-1 $\beta$ was independent of protein kinase $A$ and protein kinase $\mathbf{G}$ activity.

Conclusions-IL-1ß directly inhibits parietal cell carbachol stimulated acid secretion. This action occurs distal to muscarinic receptor activation and elevations in intracellular calcium and requires PKC.

(Gut 2001;48:782-789)

Keywords: carbachol; gastric acid; interleukin $1 \beta$; parietal cell; protein kinase $\mathrm{C}$; sphingomyelinase

Interleukin $1 \beta$ (IL-1 $\beta$ ) is a potent inhibitor of gastric acid secretion. ${ }^{1}$ The mechanisms mediating this acid inhibitory effect are complex; the cytokine acts centrally to inhibit acid secretion ${ }^{2}$ but in vitro studies have also shown that IL-1 $\beta$ has inhibitory actions against both the acid secreting parietal cell ${ }^{3-5}$ and the histamine secreting enterochromaffin-like (ECL) cell. ${ }^{6}$ Expression of IL-1 $\beta$ in the gastric mucosa is increased by inflammation, infection, and ulceration $^{7}$ and it is possible that this local production is important in local regulation of acid secretion. Increased IL- $1 \beta$ production is seen at the edges of gastric ulcers and it may be that inhibition of acid secretion is an important part of the repair mechanism by limiting further damage. $^{89}$

Previous studies have shown complex regulation of parietal cell acid secretion by IL-1 $\beta$. Inhibition of histamine stimulated acid secretion occurred via a tyrosine kinase and pertussis toxin sensitive inhibitory G protein dependent pathway reducing cAMP generation. ${ }^{3}$ However, the inhibitory actions of IL-1 $\beta$ against carbachol stimulated acid secretion seemed to be independent of these mechanisms. ${ }^{3}$ A variety of studies have shown that protein kinase C (PKC) has important inhibitory roles in parietal cells, ${ }^{10}{ }^{11}$ and that the sphingomyelinase/ceramide signalling pathway may mediate important biological effects of IL-1 $\beta .^{12}$ Therefore, the role of these two messenger systems in mediating the inhibitory actions of IL-1 $\beta$ against carbachol stimulated acid secretion in cultured rabbit parietal cells were examined.

\section{Methods}

PARIETAL CELL PREPARATION

Rabbit parietal cells were isolated from New Zealand white rabbits and enriched using previously described methods. ${ }^{14}$ Gastric fundic mucosa was digested with sequential exposure to collagenase (type I $0.175 \mathrm{~g} / 1$ with type $\mathrm{H}$ $0.175 \mathrm{~g} / \mathrm{l}$ ) and EDTA. Parietal cells were enriched from the crude suspension using a Beckman JE 5.0 elutriator rotor using the standard elutriation chamber. Parietal cells were enriched to $>70 \%$ homogeneity and $>98 \%$ viability, as determined by trypan blue exclusion.

Abbreviations used in this paper: BSA, bovine serum albumin; CHL, chelerythrine; db-cGMP, guanosine 3', 5'cyclic monophosphate; DMEM, Dulbecco's modified Eagle's medium; EBSS, Earle's balanced salt solution; EGTA, ethylene glycol-bis(beta-aminoethyl ether)- $N, N, N^{\prime}, N^{\prime}$-tetra acetic acid; EGF, epidermal growth factor; ECL, enterochromaffin-like; HBSS, Hanks' balanced salt solution; HEPES,

$N$-2-hydroxyethylpiperazine- $N$ '-ethansulphonic acid; IL-1 $\beta$, interleukin $1 \beta$; MLCK, myosin light chain kinase; PKA, protein kinase A; PKC, protein kinase C; PKG, protein kinase G; PMA, phorbol-12-myristate-13-acetate. 
CELL CULTURE

Harvested cells from the parietal cell enriched fractions were collected by brief centrifugation, pooled, and resuspended in complete culture medium (Ham's F12/Dulbecco's modified Eagle's medium (DMEM) 50/50 nutrient mix, containing $10 \%$ heat inactivated fetal calf serum, $10 \mathrm{mM} \mathrm{N}$-2-hydroxyethylpiperazine$N$ '-ethansulphonic acid (HEPES), $\mathrm{pH} 7.4,100$ $\mathrm{mg} / 1$ gentamicin, $100 \mathrm{mg} / 1$ streptomycin, 100 $\mathrm{mg} / \mathrm{l}$ penicillin, $2 \mathrm{mM}$ glutamine, $8 \mu \mathrm{g} / \mathrm{ml}$ hydrocortisone, and $1 \mu \mathrm{g} / \mathrm{ml}$ insulin) and cultured by plating $0.5-1.0 \times 10^{6}$ cells/well onto 24 well Matrigel coated tissue culture plates (Corning). The Matrigel coated plates had been prepared by diluting Matrigel 1:7 with sterile water and uniformly coating the wells. ${ }^{14}$ The parietal cell enriched fraction was cultured at $37^{\circ} \mathrm{C}$ in an atmosphere of $5 \% \mathrm{CO}_{2} / 95 \%$ air for 40 hours.

MEASUREMENT OF ACID SECRETION

Intracellular accumulation of ${ }^{14} \mathrm{C}$ aminopyrine was used as a measure of functional acid secretory activity. ${ }^{14}$ Cultured cells in 24 well plates were washed once with $2 \mathrm{ml}$ of Earle's balanced salt solution (EBSS) containing $0.1 \%$ bovine serum albumin (BSA), $10 \mathrm{mM}$ HEPES, $\mathrm{pH}$ 7.4, $2 \mathrm{mM}$ glutamine, and $0.22 \% \mathrm{NaHCO}_{3}$ to remove dead and non-adherent cells. Thereafter, $1 \mathrm{ml}$ of the above medium was added, and $0.1 \mu \mathrm{Ci}$ aminopyrine and the stimulant substances (carbachol and A23187) were added simultaneously to each well. Cells were incubated for 30 minutes at $37^{\circ} \mathrm{C}$ in an atmosphere of $5 \% \mathrm{CO}_{2} / 95 \%$ air. Incubations were terminated by removing the medium from each well using a vacuum pump and washing twice with $1 \mathrm{ml}$ of EBSS solution. Cells were lysed with $1 \mathrm{ml}$ of $1 \%$ Triton X-100. Aliquots of cell lysates and incubation media were counted in Optiphase Safe (Wallac, Milton Keynes, UK) using a Beckman LS 1801 liquid scintillation counter with DPM correction. Dinitrophenol $(0.1 \mathrm{mM})$ was added to separate wells to assess non-specific incorporation and values were subtracted from test values. ${ }^{15} \mathrm{IL}-1 \beta$ or guanosine 3', 5'- cyclic monophosphate (db-cGMP) was added to the wells 15 minutes prior to the initial washing step before adding aminopyrine and the stimulants. PKC inhibition was affected by preincubating parietal cells for 24 hours with phorbol-12-myristate-13-acetate (PMA) (500 $\mathrm{nM}$ ) or PKC inhibitors for 60 minutes prior to assessing acid secretion. ${ }^{3}{ }^{16}$

RECEPTOR BINDING STUDIES

Muscarinic receptor binding studies were performed using a previously described method with modifications. ${ }^{17}$ Briefly, cells on Matrigel coated 12 well plates $\left(1 \times 10^{6} /\right.$ well $)$ were incubated with IL-1 $\beta(10 \mathrm{ng} / \mathrm{ml})$ for 15 minutes and washed three times with Hank's balanced salt solution (HBSS) containing $0.1 \% \mathrm{BSA}$ to remove non-adherent cells and incubated at $37^{\circ} \mathrm{C}$ with $\left[{ }^{3} \mathrm{H}\right] n$-methyl-scopolamine (specific activity $64 \mathrm{Ci} / \mathrm{mmol}, 100 \mathrm{fmol} / \mathrm{sample}$ ) in 0.5 $\mathrm{ml}$ of HBSS- $0.1 \%$ BSA and increasing concentrations of atropine for 60 minutes. Cells were washed twice with ice chilled HBSS. Adherent cells were solubilised by incubating in $1 \%$ Triton X-100 and bound and unbound radioactivity was assessed by liquid scintillation counting. $\left[{ }^{3} \mathrm{H}\right]$ Methyl-scopolamine binding in the presence of $100 \mathrm{mM}$ atropine was regarded as non-specific binding and these values were subtracted from total binding to obtain values for specific binding.

MEASUREMENT OF PKC ACTIVITY

PKC activity in parietal cell membranes was measured using a standardised assay kit (Amersham protein kinase $\mathrm{C}$ enzyme kit) ${ }^{17}$ based on phosphorylation of a synthetic peptide substrate by PKC. Isolated parietal cells $\left(10^{7}\right.$ cells $)$ in $1 \mathrm{ml}$ of EBSS containing HEPES (10 nmol/l), $\mathrm{NaHCO}_{3}(0.22 \%)$, and BSA $(0.1 \%)$ were incubated for five minutes at $37^{\circ} \mathrm{C}$ with IL-1 $\beta(10 \mathrm{ng} / \mathrm{ml})$, epidermal growth factor (EGF) (100 nM), or PMA (100 nM). Ice chilled phosphate buffer saline $(1 \mathrm{ml})$ was added to quench the reaction and cells were immediately centrifuged. Membranes were prepared by resuspending cells in $1 \mathrm{ml}$ of sonicate buffer $(50 \mathrm{mM}$ Tris $\mathrm{HCl}, \mathrm{pH} 7.5,5 \mathrm{mM}$ EDTA, $10 \mathrm{mM}$ ethylene glycol-bis(betaaminoethyl ether)- $N, N, N^{\prime}, N^{\prime}$-tetra acetic acid (EGTA), $0.3 \% \quad \beta$-mercaptoethanol, $10 \mathrm{mM}$ benzamidine, and $25 \mathrm{mg} / \mathrm{ml}$ phenylmethylsulphonyl fluoride) on ice and sonicated twice for 15 seconds. Sonicates were centrifuged at $1000 \mathrm{~g}$ for five minutes at $4^{\circ} \mathrm{C}$. Supernatants were centrifuged at $12000 \mathrm{~g}$ for 25 minutes at $4^{\circ} \mathrm{C}$. The membrane containing pellets were resuspended in sonicate buffer and stored at $-70^{\circ} \mathrm{C}$. Total PKC activity in membranes (30-60 mg protein) was measured in a final volume of $100 \mathrm{ml}$ containing $50 \mathrm{mM}$ Tris $\mathrm{HCl}$, $0.05 \%$ sodium azide, $\mathrm{pH} 7.5,24 \mathrm{mg} / \mathrm{ml}$ PMA, $900 \mathrm{mM}$ peptide, $300 \mathrm{mM}$ dithiothreitol, 150 $\mathrm{mM}$ adenosine triphosphate, $45 \mathrm{mM}$ magnesium acetate, and $1 \times 10^{6}$ counts $/ \mathrm{min}$ of $\gamma-\left[{ }^{32} \mathrm{P}\right]$ adenosine triphosphate (Amersham specific activity $1.66 \mathrm{mCi} / \mathrm{ml})$. The reaction mixture was incubated for 15 minutes at $25^{\circ} \mathrm{C}$ and stopped by adding $100 \mathrm{ml}$ of stop solution. A sample of the final reaction mixture $(125 \mathrm{ml})$ was pipetted onto binding paper $(2.5 \times 2.5 \mathrm{~cm})$. Phosphorylated peptide was separated onto binding paper. The paper was washed twice with $5 \%$ acetic acid and phosphorylation was detected by scintillation counting.

CHEMICALS AND DRUGS

Carbachol, A23187, atropine, staphylococcal sphingomyelinase, and recombinant human IL-1 $\beta$ were purchased from Sigma (Poole, UK). Recombinant human EGF, db-cGMP, $\mathrm{H}-8, \mathrm{H}-89$, and $\mathrm{C} 2$-ceramide were from Calbiochem (Nottingham, UK). Staurosporine, $\mathrm{H}-7$, and chelerythrine (CHL) were from LC laboratories (Nottingham, UK). Triton X-100 and HEPES were from BDHMerck (Poole, UK) ${ }^{14} \mathrm{C}$-dimethylamineaminopyrine $(103 \mathrm{mCi} / \mathrm{mmol})$ and $\left[{ }^{3} \mathrm{H}\right] n$ methyl-scopolamine $(64 \mathrm{Ci} / \mathrm{mmol})$ were obtained from Amersham International (Amersham, UK). Ham's F12/DMEM (50:50 $\mathrm{vol} / \mathrm{vol}$ ), glutamine, HBSS, basal medium Eagle's, and fetal calf serum were obtained 
from Gibco (Paisley, UK). Basement membrane Matrigel was from Universal Biologicals (London, UK.). All other reagents were from Sigma.

STATISTICAL ANALYSIS

All data are presented as mean (SEM) of 3-7 separate cell preparations. Data were compared using one way analysis of variance and the Student's $t$ test to determine significance. A $\mathrm{p}$ value of $<0.05$ was regarded as significant.

\section{Results}

EFFECT OF IL-1 $\beta$ ON STIMULATED ACID

SECRETION

Carbachol effectively stimulated acid secretion in cultured rabbit parietal cells; $100 \mathrm{mM}$ increased acid secretion by 155 (10)\%. The calcium ionophore A23187 (1 mM), used to mimic post-receptor signalling (elevations in $\left[\mathrm{Ca}^{2++}\right]_{\mathrm{i}}$ ) initiated by carbachol, was also an effective stimulant of acid secretion, increasing acid secretion by $80(15) \%$. IL- $1 \beta$ inhibited the stimulatory activities of both carbachol and A23187. Maximal inhibition of acid secretion was seen with $10 \mathrm{ng} / \mathrm{ml} \mathrm{IL-1 \beta}$ (carbachol by 36 (4) \%, A23187 by $38(4) \%$ ) and this concentration was used for further studies (fig 1).

EFFECT OF PKC MODULATION ON IL- $1 \beta$

INHIBITION OF ACID SECRETION

The three different PKC inhibitors had no effect on basal or stimulated acid secretion. All three agents (staurosporine (100 nM), H-7
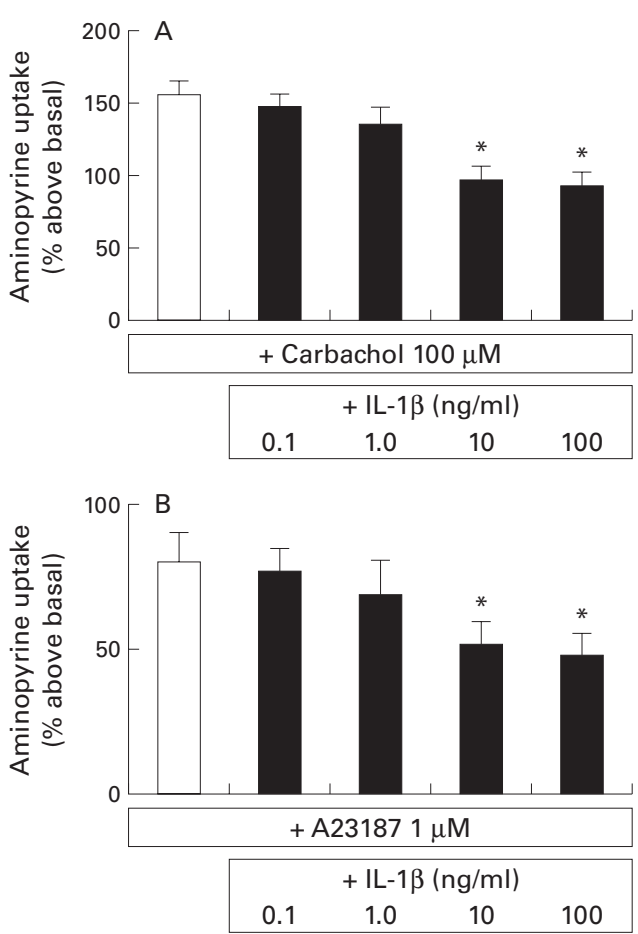

Figure 1 Effect of increasing concentrations of interleukin $1 \beta$ (IL-1 $\beta$ ) on parietal cell acid secretion stimulated by carbachol $(A)$ and the calcium ionophore A23187 (B). Parietal cells were incubated with IL-1 $\beta$ for 15 minutes before stimulation of acid secretion. Results are expressed as per cent aminopyrine uptake above unstimulated basal over 30 minutes (mean (SEM), $n=4$ ). ${ }^{*} p<0.05$ compared with appropriate agonist stimulated control.
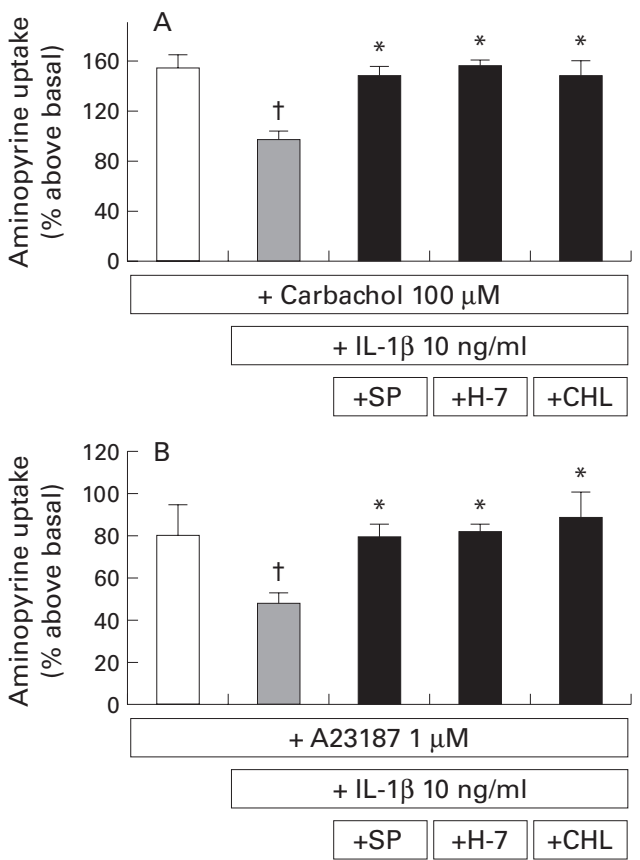

Figure 2 Effect of protein kinase $C$ inhibitors on interleukin $1 \beta$ (IL-1 $\beta$ ) inhibition of carbachol $(A)$ and A23187 (B) stimulated parietal cell acid secretion. Parietal cells were incubated with staurosporine $100 \mathrm{nM}(\mathrm{SP}), \mathrm{H}-7$ $100 \mathrm{nM}(\mathrm{H}-7)$, or chelerythrine $10 \mathrm{mM}$ (CHL) for 60 minutes prior to exposure to $I L-1 \beta 10 \mathrm{ng} / \mathrm{ml}$ for 15 minutes. Results are expressed as per cent aminopyrine uptake above unstimulated basal over 30 minutes (mean (SEM), $n=7$ ). $t p<0.05 v$ stimulant alone, ${ }^{\star} p<0.05 v$ stimulant $+I L-1 \beta$.

(100 $\mathrm{nM})$, and CHL (10 $\mathrm{mM})$ ) abolished the inhibitory effects of IL- $1 \beta$ against carbachol and A23187 stimulated acid secretion (fig 2).

CHL reversed inhibition of carbachol stimulated acid secretion by IL- $1 \beta$ in a dose dependent manner (fig 3).

Pretreatment with high dose PMA (500 nM for 24 hours) to deplete cellular active PKC itself caused a small decrease in stimulated acid secretion but completely abolished the inhibitory effects of IL-1 $\beta$ against carbachol and A23187 stimulated acid secretion (fig 4).

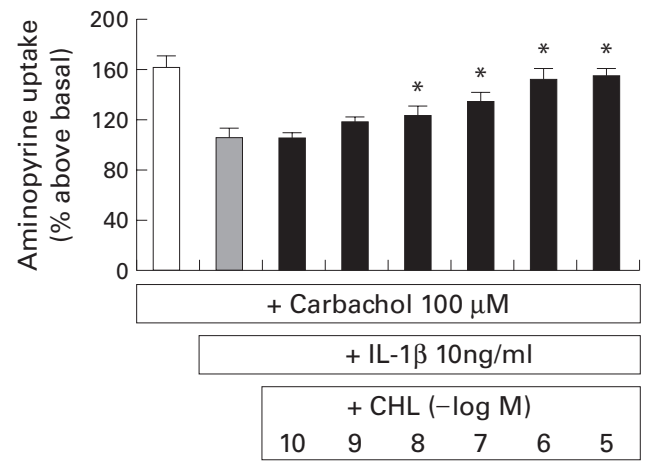

Figure 3 Dose response relationship of the protein kinase $C$ inhibitor chelerythrine (CHL) against interleukin $1 \beta$ (IL-1B) inhibition of carbachol stimulated acid secretion. Parietal cells were incubated with increasing concentrations of CHL for 60 minutes prior to exposure to IL-1 $\beta$ (10 $\mathrm{ng} / \mathrm{ml}$ ) for 15 minutes. Acid secretion was then stimulated by carbachol $100 \mu M$ for 30 minutes. Results are expressed as per cent above unstimulated basal (mean (SEM), $n=3$ ). ${ }^{\star} p<0.05$ v carbachol $+I L-1 \beta$. 

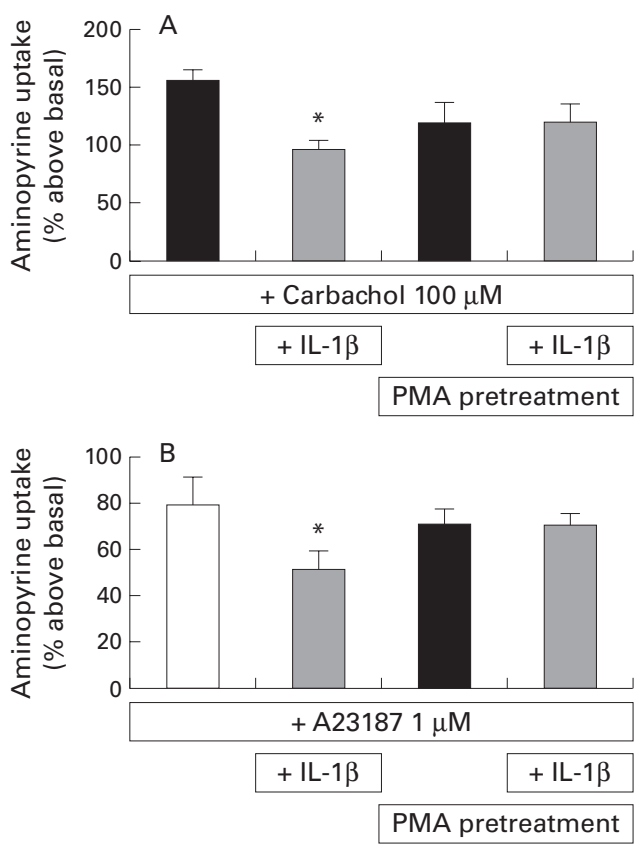

Figure 4 Effect of protein kinase $C$ depletion on interleukin $1 \beta(I L-1 \beta)$ inhibition of carbachol $(A)$ and A23187 (B) stimulated parietal cell acid secretion. Parietal cells were incubated with the active phorbol ester, phorbol-12-myristate-13-acetate (PMA) $500 \mathrm{nM}$ for 24 hours before acid secretion with or without IL-1 $\beta$ (10 $\mathrm{ng} / \mathrm{ml}$ ) was assessed. Results are expressed as per cent aminopyrine uptake above identically treated unstimulated controls (mean (SEM), $n=4) .{ }^{\star} p<0.05$ compared with agonist stimulated acid secretion in the absence of $I L-1 \beta$.

EFFECT OF IL- $1 \beta$ ON $\left[{ }^{3} \mathrm{H}\right]$ METHYL-SCOPOLAMINE BINDING TO PARIETAL CELLS

Pretreatment of parietal cells with IL- $1 \beta$ in an acid inhibitory concentration $(10 \mathrm{ng} / \mathrm{ml}) \mathrm{did}$ not alter binding to the muscarinic receptor (fig 5).

EFFECT OF IL-1 $\beta$ ON PARIETAL CELL MEMBRANE PKC ACTIVITY

PKC activity in parietal cell membranes was increased by acid inhibitory concentrations of IL-1 $\beta$. PKC activity was increased by 50 (6)\%. This effect was less than that seen with the two positive controls, the phorbol ester PMA 100 $\mathrm{nM}$ and EGF $100 \mathrm{nM}$ (fig 6). ${ }^{17}$

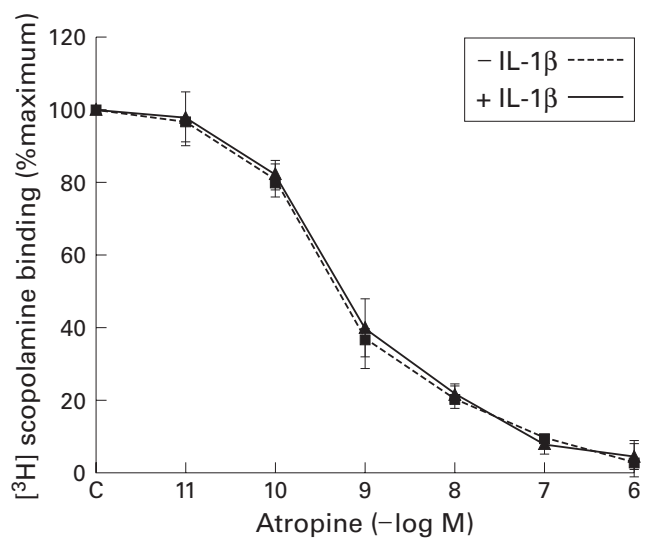

Figure 5 Effect of interleukin $1 \beta(I L-1 \beta)(10 \mathrm{ng} / \mathrm{ml})$ on $[$ H] methyl-scopolamine binding to parietal cells. Parietal cells were pretreated with $I L-1 \beta$ for 15 minutes before 60 minutes incubation with [ $\mathrm{H}]$ methyl-scopolamine and increasing concentrations of atropine (mean (SEM), $n=3$ ).

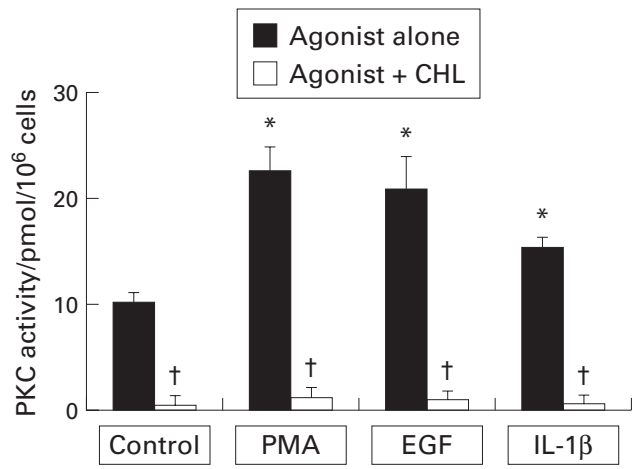

Figure 6 Effect of phorbol ester (PMA 100 nM), epidermal growth factor (EGF $100 \mathrm{nM})$, interleukin $1 \beta$ $(I L-1 \beta)(10 \mathrm{ng} / \mathrm{ml})$, and chelerythrine (CHL $10 \mathrm{mM})$ on protein kinase $C$ (PKC) activity in parietal cell

membranes. Parietal cells were stimulated with agonists for five minutes before membrane PKC activity was assessed. Parietal cells were exposed to CHL for 60 minutes prior to adding other agonists. Results are expressed as pmol/10 cells (mean (SEM), $n=4)$. ${ }^{*} p<0.05$ compared with basal, $t p<0.05$ compared with agonist stimulated PKC activity in the absence of CHL.

PMA (by 29 (7)\%) and EGF (by 40 (4)\%) were effective in inhibiting carbachol stimulated acid secretion (fig 7). CHL (10 $\mu \mathrm{M})$ abolished basal and agonist stimulated membrane PKC activity (fig 6) and reversed the acid inhibitory action of IL- $1 \beta$ as well as PMA and EGF (fig 7).

EFFECT OF MANIPULATION OF PROTEIN KINASES A AND G ON IL- $1 \beta$ INHIBITION OF ACID SECRETION Addition of the cell permeable cGMP analogue db-cGMP $(100 \mu M)$ inhibited carbachol stimulated acid secretion by $25(4) \%$. This was completely ameliorated by pretreatment with $\mathrm{H}-8(0.1 \mu \mathrm{M})$ (fig 8). This concentration of H-8 had no effect on the inhibitory action of IL-1 $\beta$ (fig 8). The protein kinase A (PKA) inhibitor H-89 (10 nM) had no effect on basal or carbachol stimulated acid secretion. Similarly, $\mathrm{H}-89$ did not alter the inhibitory actions of IL-1 $\beta$ or db-cGMP (fig 8).

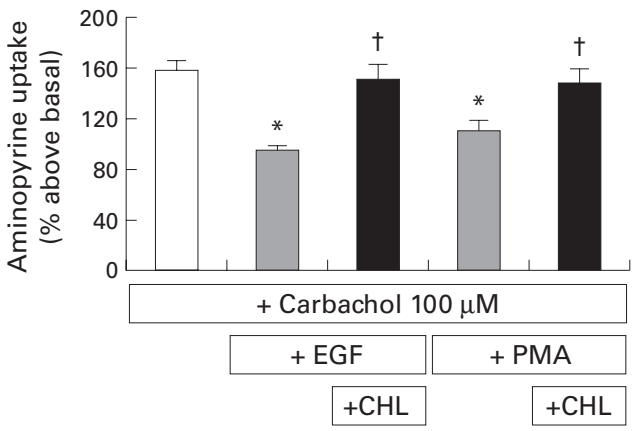

Figure 7 Effect of protein kinase $C$ activation with phorbol ester (PMA) and epidermal growth factor (EGF) on carbachol stimulated acid secretion. Parietal cells were

incubated with PMA or EGF (both $100 \mathrm{nM}$ ) for 15 minutes before stimulation of acid secretion. Chelerythrine (CHL) $10 \mathrm{mM}$ was added 60 minutes prior to protein kinase $C$ activators. Results are expressed as per cent aminopyrine uptake above unstimulated basal over 30 minutes (mean (SEM), $n=3$ ). ${ }^{*} p<0.05$ compared with carbachol stimulated control, $t p<0.05$ compared with effect of EGF or PMA in the absence of CHL. 

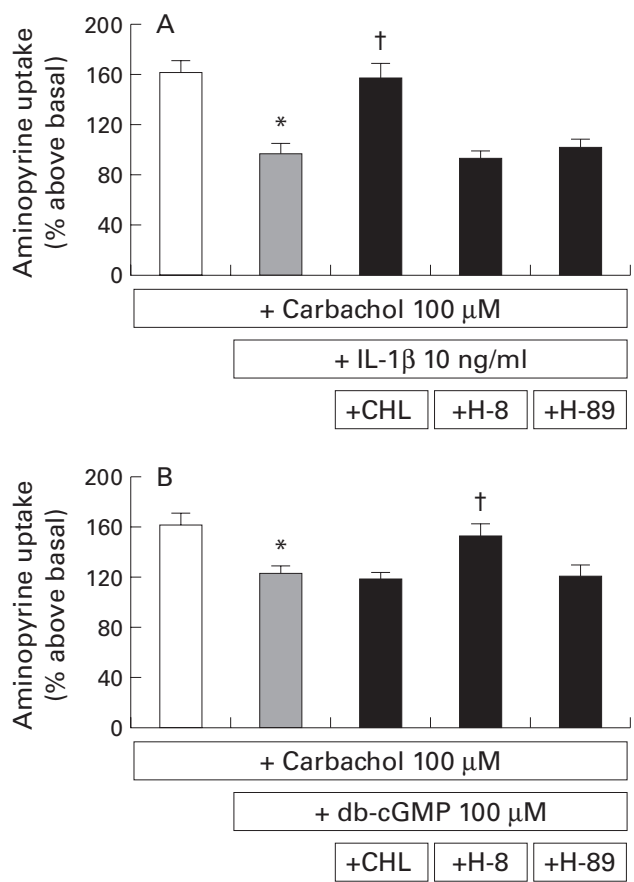

Figure 8 Effect of protein kinase inhibitors on modulation of acid secretion in parietal cells. The protein kinase $C$ (chelerythrine, $C H L 10 \mu \mathrm{M})$, protein kinase $G(H-80.1$ $\mu M)$, and protein kinase $A(H-8910 n M)$ inhibitors were added 60 minutes prior to exposure of parietal cells to either interleukin $1 \beta(I L-1 \beta)(A)$ or guanosine 3', 5'- cyclic monophosphate (db-cGMP) (B) and stimulation of acid secretion with carbachol (mean (SEM), $n=4)$. ${ }^{\star} p<0.05$ compared with carbachol stimulated acid secretion, $t p<0.05$ compared with effects of $I L-1 \beta$ or $d b-c G M P$.
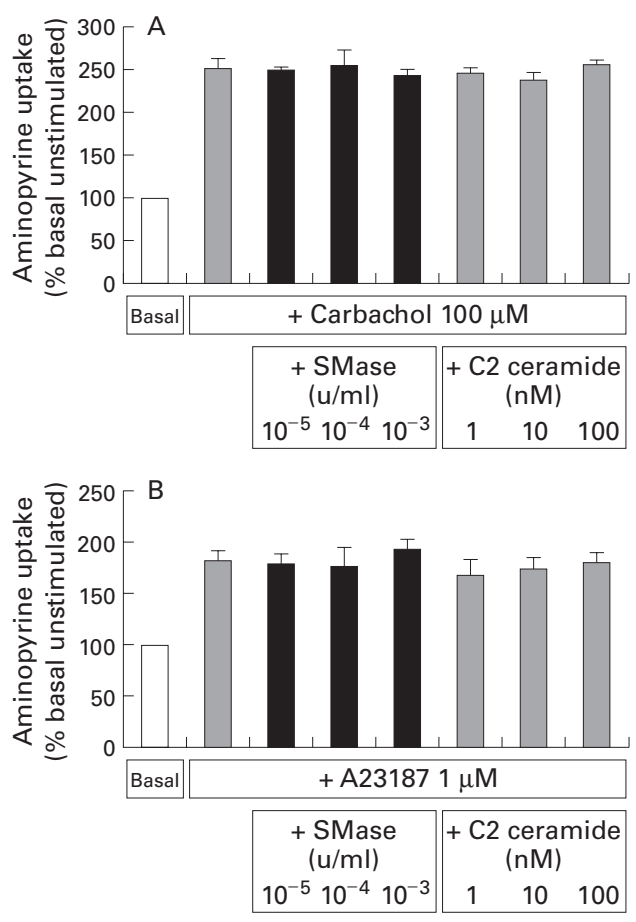

Figure 9 Effect of activation of the sphingomyelinase signalling pathway on carbachol $(A)$ and $A 23187(B)$ stimulated acid secretion. Parietal cells were incubated with increasing concentrations of sphingomyelinase (SMase) or C2 ceramide for 15 minutes prior to assessing acid secretion. Results are expressed as per cent unstimulated basal aminopyrine uptake (mean (SEM), $n=4)$.
EFFECT OF ACTIVATION OF THE SPHINGOMYELINASE/CERAMIDE PATHWAY

Exogenous sphingomyelinase and the cell wall permeable C2 ceramide had no effect on basal, or A23187 or carbachol stimulated acid secretion. Similarly, no enhancement or reversal of the inhibitory effects of IL- $1 \beta$ were apparent with either agent (fig 9). Biological activity of C2 ceramide and sphingomyelinase was confirmed by the ability to induce interleukin 8 production in cultured AGS cells ${ }^{16} 18$

\section{TOXICITY}

Morphology and toxicity were assessed in parallel experiments with all agents used. No alteration in parietal cell morphology, or impairment of cell viability, as assessed by trypan blue exclusion or lactate dehydrogenase release, ${ }^{19}$ was seen under any experimental condition, either following the 30 minute stimulation period or after washing the cells and continuing culture in complete culture medium for a further 24 hours.

\section{Discussion}

This study demonstrates that IL- $1 \beta$ directly inhibits acid secretion by isolated cultured parietal cells. The mechanism is dependent on PKC and the inhibitory action is at a point distal to the generation of increased intracellular calcium as a second messenger. IL- $1 \beta$ effectively inhibited both carbachol and A23187 induced acid secretion showing that the inhibitory action against carbachol stimulated acid secretion is unlikely to be mediated by inhibiting rises in $\left[\mathrm{Ca}^{2+}\right]_{\mathrm{i}}$. These data are consistent with the finding that IL- $1 \beta$ did not inhibit muscarinic receptor binding at concentrations which were effective at inhibiting acid secretion, and thus the inhibitory action of IL-1 $\beta$ does not appear to involve direct inhibition of either receptor binding or early signal transduction.

The inhibitory actions of IL- $1 \beta$ were blocked by manoeuvres which inhibited PKC. Three different inhibitors all effectively blocked the action of IL-1 $\beta$. Depletion of cellular PKC with high dose phorbol ester was similarly effective, confirming the essential nature of this pathway in the inhibitory actions of IL- $1 \beta$. IL- $1 \beta$ increased the activity of PKC in parietal cell membranes. Increased membrane associated activity represents translocation of inactive cytosolic enzyme to the cytoplasmic leaflet of the plasma membrane and subsequent activation early in receptor mediated signalling pathways. ${ }^{17}$ This increase in kinase activity further supports the role of PKC in mediating the inhibitory effects of IL- $1 \beta$.

The PKC inhibitor CHL abolished both IL-1 $\beta$ inhibition of acid secretion and IL- $1 \beta$ stimulation of membrane PKC activity. CHL also abolished the increase in membrane associated PKC activity and the acid inhibitory actions of the two positive controls (PMA and EGF). This strongly suggests that increased PKC activity is essential for inhibition of acid secretion.

While these kinase inhibitors are not absolutely specific for $\mathrm{PKC},{ }^{17}$ the corresponding 
actions of the three different agents, combined with data on PKC depletion by a PKC specific agent as well as increased PKC activity levels following IL-1 $\beta$ treatment, strongly implicate PKC in the pathway mediating the effects of IL- $1 \beta$.

One potential criticism of all studies requiring kinase inhibitors is the lack of specificity against target kinases. In addition to the actions utilised within the study, all of the agents have the ability to block the activity of other intracellular enzymes, such as PKA (cAMP activated kinase), protein kinase $G$ (PKG) (cGMP activated kinase), myosin light chain kinase (MLCK), and calmodulin kinase. The concentrations used were carefully chosen to enhance the specificity of the actions and control experiments performed to assess the effects of the other kinases. Staurosporine and $\mathrm{H}-7$ are potent but relatively non-specific PKC inhibitors. The $K_{i}$ value for $\mathrm{H}-7$ against PKC is $6 \mu \mathrm{M}$ compared with MLCK $97 \mu \mathrm{M}$, PKA $3.0 \mu \mathrm{M}$, and PKG $5.8 \mu \mathrm{M}^{20-23}$ Staurosporine inhibits PKC with an $\mathrm{IC}_{50}$ of $0.7 \mathrm{nM}$ compared with $7.0 \mathrm{nM}$ for PKA and $8.5 \mathrm{nM}$ for PKG. ${ }^{22}{ }^{24-27}$ $\mathrm{CHL}$ is a less potent but a more specific PKC inhibitor, the $\mathrm{IC}_{50}$ for $\mathrm{PKC}$ is $660 \mathrm{nM}$ compared with $>0.1 \mathrm{mM}$ for PKA, tyrosine kinase, and calmodulin kinase. ${ }^{28}{ }^{29} \mathrm{CHL}$, at concentrations used in this study, selectively inhibits PKC compared with MLCK. ${ }^{30}$ MLCK and calmodulin kinase are essential parts of the signalling pathway leading to acid secretion subsequent on activation of the parietal cell. ${ }^{31} 32$ Stimulation of these pathways appears to increase acid secretion and thus they are unlikely to be activated by IL- $1 \beta$, which clearly inhibits acid secretion. The consistency of results with the three PKC inhibitors at the concentrations used would seem to confirm this.

The potential role of the cyclic nucleotide dependent kinases was studied with $\mathrm{H}-8$ and $\mathrm{H}-89 . \mathrm{H}-8$ is a potent inhibitor of PKG $\left(K_{\mathrm{i}} 480\right.$ $\mathrm{nM})$ and significantly less potent against PKA $\left(K_{\mathrm{i}} 1.2 \mu \mathrm{M}\right)$, MLCK $(68 \mu \mathrm{M})$, and PKC $(15$ $\mu M) .^{34}$ Selectively for PKG is usual at the concentration used here of $100 \mathrm{nM} \cdot{ }^{34}$ Activation of PKG with db-cGMP inhibited carbachol stimulated acid secretion, as has been reported previously. ${ }^{35} 36$ This effect was blocked by $\mathrm{H}-8$. No effect of $\mathrm{H}-8$ against IL- $1 \beta$ inhibition of acid secretion was demonstrated, suggesting that PKG is not involved in IL-1 $\beta$ mediated acid inhibition. $\mathrm{H}-89$ is a potent PKA inhibitor $\left(K_{\mathrm{i}} 48 \mathrm{nM}\right)$; it has been used effectively to selectively distinguish the effects of PKA.${ }^{17}{ }^{37}$ In this study inhibition of PKA did not alter the inhibitory action of IL-1 $\beta$. Thus within the constraints of studies utilizing kinase inhibitors, by using carefully chosen concentrations and combinations of inhibitors, this study strongly implicates PKC as an essential part of the IL-1 $\beta$ activated signalling pathway.

Different PKC isoforms have been detected in parietal cells. It has been demonstrated previously that EGF inhibits carbachol stimulated acid secretion via a PKC dependent mechanism, also acting distally to generation of increased $\left[\mathrm{Ca}^{++}\right]_{\mathrm{i}}{ }^{17} \mathrm{PKC}$ has a complex role in the regulation of acid secretion in parietal cells. Some acute stimulatory action has been demonstrated but the majority of studies suggest PKC has an inhibitory role which may be mediated by receptor downregulation and at more distal points in the acid secretion pathway. ${ }^{11} 1738$ This current study further supports the important role of PKC in mediating the effects of a variety of extracellular inhibitors of acid secretion.

A variety of PKC isoforms have been demonstrated in parietal cells although the specific role of any of these remains to be clarified and data on the distribution and function of each are scanty and often conflicting. Muramatsu et al demonstrated alpha, gamma, and zeta mRNA by northern blotting in guinea pig parietal cells but did not provide data on the distribution or activity. ${ }^{39}$ In canine parietal cells EGF increased membrane associated PKC activity and the translocation of the $\mathrm{Ca}^{2+}$ dependent $\alpha$ and $\beta 1$ isoforms to the cell membrane. ${ }^{17}$ It has been suggested that the so-called "atypical" $\mathrm{Ca}^{2+}$ independent isoforms may have important roles in regulating inhibitory pathways in parietal cells. Chew et al demonstrated with immunoblotting that rabbit parietal cells express abundant levels of the epsilon, $\mathrm{mu}$, iota, lambda, and zeta protein isoforms but relative paucity of alpha and beta 1 and beta 2. ${ }^{10}$ McKenna et al showed that PKC- $\alpha$ mediated the inhibitory effect of phorbol ester on histamine $\mathrm{H}_{2}$ receptor activation of adenylate cyclase in HGT-1 cells. ${ }^{40}$ Activation of PKC isoforms by IL-1 $\beta$ may be important in parietal cell regulation and recent work has identified important roles for PKC-lambda/ iota, ${ }^{41}$ epsilon, and delta ${ }^{42}$ in NIH 3 T 3 cells and PKC-zeta in Schwann cells ${ }^{13}$ in mediating the effects of IL-1 $\beta$. As yet the PKC isoforms involved in IL-1 $\beta$ signal transduction within parietal cells remain to be elucidated. IL- $1 \beta$, EGF, and PMA inhibited acid secretion by an equivalent amount, despite a greater increase in membrane PKC activity with EGF and PMA. This may imply that specific isoforms are responsible for inhibition of acid secretion. The apparent lack of direct relationship between measured PKC activity and inhibition of acid secretion may be due to total PKC enzyme activity being assessed and that isoforms are activated by PMA and EGF which are not immediately related to regulation of acid secretion.

Further studies will be performed using more isozyme specific inhibitors and immunoblotting to attempt to determine the exact significance of the different PKC isoforms, cellular location, and translocation in the regulation of parietal cell function.

A variety of signal transduction pathways mediating the many biological effects of IL- $1 \beta$ have been described. Many actions of IL- $1 \beta$ are dependent on $G$ protein coupled stimulation of cAMP formation and activation of PKA. ${ }^{43}$ Increased levels of cAMP stimulate acid secretion in parietal cells ${ }^{44}$ and our previous studies did not demonstrate any role for $G$ protein coupled pathways mediating the inhibitory actions of IL-1 $\beta$ against carbachol stimulated 
acid secretion. ${ }^{3}$ The lack of effect of $\mathrm{H}-89$, used at a concentration specific for the inhibition of PKA, ${ }^{37}$ is also strongly suggestive of the inhibitory actions of IL- $1 \beta$ not being mediated via the adenylate cyclase/cAMP/PKA pathway.

In other systems the biological actions of IL-1 $\beta$ subsequent to receptor binding appear to be mediated by activation of sphingomyelinases in the cell membrane and liberation of ceramide second messenger. ${ }^{12}$ Exogenous sphingomyelinase and cell permeable ceramide analogues have been used to explore the biological role of this system. ${ }^{18}$ No effect of biologically active ceramide or sphingomyelinase on acid secretion was demonstrated. Thus the current data do not support a role for this pathway in mediating control of parietal cell acid secretion by IL- $1 \beta$.

Previously, we have shown that tumour necrosis factor $\alpha$ inhibited carbachol stimulated secretion via a tyrosine kinase pathway. ${ }^{3}$ Although some of the varied biological effects of IL- $1 \beta$ are mediated by tyrosine kinases, ${ }^{16}$ previous studies demonstrated that the inhibitory action against carbachol stimulated acid secretion was independent of tyrosine kinase activity. $^{3}$

Several of the agents used within this study have the ability to induce toxicity or apoptosis in various cellular models. ${ }^{45}{ }^{46} \mathrm{~A}$ portion of the inhibitory action of IL- $1 \beta$ against ECL cells is due to decreased cell viability. ${ }^{6}$ We failed to demonstrate any reduction in parietal cell viability or alteration in morphology, even at 24 hours after exposure to test agents. Thus it seems unlikely that any alterations in acid secretion occurred as a secondary phenomena to toxicity or apoptosis.

IL-1 is a potent inhibitor of acid secretion when administered parenterally ${ }^{47}$ or intracisternally $^{2}$; at least some of these inhibitory actions are mediated by direct inhibition of parietal ${ }^{3}$ and ECL cell function. ${ }^{6}$ Recent studies have both confirmed an inhibitory action of IL-1 $\beta$ and demonstrated the presence of IL- $1 \beta$ receptor and corresponding mRNA in highly enriched populations of rabbit parietal cells. ${ }^{5}$ IL-1 may be an important pathophysiological regulator of acid secretion. Inhibition of acid secretion is seen in systemic sepsis and disease. Profound hypochlorhydria may be seen in acute and chronic Helicobacter pylori infection, ${ }^{48-50}$ where it is associated with increased expression of IL- $1 \beta .{ }^{74}$ Cytokine overexpression and acid secretion return towards normal with eradication of the infection. ${ }^{49}{ }^{51}$ Low levels of IL-1 $\beta$ may be expressed in normal healthy gastric mucosa, ${ }^{7}$ suggesting that the cytokine may have a physiological role in the control of acid secretion along with the other luminal, paracrine, endocrine, and neurocrine factors.

In conclusion, this study demonstrates that IL-1 $\beta$ inhibits carbachol stimulated acid secretion in cultured parietal cells. This effect occurs distal to second messenger generation and appears to involve a PKC dependent pathway but is independent of PKA, PKG, and ceramide/sphingomyelinase. The exact PKC isoforms and their precise roles will be determined in the future.

This work was supported by the Medical Research Council in the form of a Research Training Fellowship for ILPB. This work was presented and published in abstract form at the 6th UEGW (Birmingham 1997; Gut 1997;41 (suppl 3): A95) and the British Society of Gastroenterology (Harrogate 1998; Gut 1998;42(suppl 1): F98).

1 Wallace JL, Cucala M, Mugridge K, et al. Secretagoguespecific effects of interleukin-1 on gastric acid secretion. Am F Physiol 1991;261:G559-64.

2 Saperas ES, Yang H, Rivier C, et al. Central action of recombinant interleukin-1 to inhibit acid secretion in rats. Gastroenterology 1990;99:1599-606.

3 Beales I, Calam J. Interleukin-1 $\beta$ and tumour necrosis factor- $\alpha$ inhibit acid secretion in cultured rabbit parietal cells by multiple pathways. Gut 1998;42:227-34.

4 Nompleggi DJ, Beinborn M, Roy A, et al. The effect of recombinant cytokines on [14C]-aminopyrine accumulation by isolated canine parietal cells. F Pharmacol Exp Ther 1994;270:440-5.

5 Schepp W, Dehne K, Herrmuth $\mathrm{H}$, et al. Identification and functional importance of IL-1 receptors on rat parietal cells. Am f Physiol 1998;275:G1094-105.

6 Prinz C, Neumayer N, Mahr S, et al. Functional impairment Prinz C, Neumayer N, Mahr S, et al. Functional impairment
of rat enterochromaffin-like cells by interleukin 1 beta. of rat enterochromaffin-like cells

7 Yamaoka Y, Kita M, Kodama T, et al. Induction of various cytokines and development of severe mucosal inflammation by cagA gene positive Helicobacter pylori strains. Gut 1997;41:442-51.

8 Tache Y, Saperas E. Potent inhibition of gastric acid secretion and ulcer formation by centrally and peripherally administered interleukin-1. Ann N Y Acad Sci 1992;664: 353-68.

9 Wahlstrom KJ, Knudsen K, Lee JI, et al. Sequential changes in IL-1 alpha and TNF-alpha expression during healing of experimental gastric ulcers. Gastroenterology 1995;108: A251.

10 Chew CS, Zhou CJ, Parente JA Jr. $\mathrm{Ca}^{2+}$-independent protein kinase $\mathrm{C}$ isoforms may modulate parietal cell $\mathrm{HCl}$ secretion. Am f Physiol 1997;272:G246-56.

11 Nandi J, Bosche MC, Levine RA. Effects of a phorbol ester and isoquinoline sulfonamides on rabbit parietal cell funcand isoquinoline sulfonamides on rabbit pariet

12 Saklatvala J. Intracellular signalling mechanisms of interleukin 1 and tumour necrosis factor: possible targets for therapy. Br Med Bull 1995;51:402-18.

13 Carlson CD, Hart RP. Activation of acidic sphingomyelinase and protein kinase $\mathrm{C}$ zeta is required for IL-1 induction of LIF mRNA in a Schwann cell line. Glia 1996;18:49-58.

14 Beales I, Calam J. Effect of Nalpha-methyl-histamine on acid secretion in isolated cultured rabbit parietal cells: implications for Helicobacter pylori associated gastritis and gastric physiology. Gut 1997;40:14-9.

15 Wang L, Lucey MR, Fras AM, et al. Epidermal growth factor and transforming growth factor-alpha directly inhibit parietal cell function through a similar mechanism. F Pharmacol Exp Ther 1993;265:308-13.

16 Beales I, Calam J. Stimulation of IL-8 production in human gastric epithelial cells by Helicobacter pylori, IL-1 $\beta$ and gastric epithelial cells by Helicobacter pylori, IL-1 $\beta$ and TNF- $\alpha$ requires tyrosine kinase actin
kinase C. Cytokine 1997;9:514-20.

17 Wang L, Wilson EJ, Osbourn J, et al. Epidermal growth factor inhibits carbachol-stimulated canine parietal cell function via protein kinase C. Gastroenterology 1996;110: 469-77

18 Masamune A, Shimosegawa T, Masamune O, et al. Helicobacter pylori-dependent ceramide production may mediate increased interleukin 8 expression in human gastric cancer cell lines. Gastroenterology 1999;116:1330-41.

19 Beales I, Blaser MJ, Srinivasan S, et al. Effect of Helicobacter pylori products and recombinant cytokines on gastrin release from cultured canine $\mathrm{G}$ cells. Gastroenterology 1997;113:465-71.

20 Boulis NM, Davis M. Blockade of the spinal excitatory effect of cAMP on the startle reflex by intrathecal administration of the isoquinoline sulfonamide $\mathrm{H}-8$ : comparison to the protein kinase C inhibitor H-7. Brain Res 1990;525: the protein

21 Quick J, Ware JA, Driedger PE. The structure and biological activities of the widely used protein kinase inhibitor, 7, differ depending on the commercial source. Biochem Biophys Res Commun 1992;187:657-63.

22 Schachtele C, Seifert R, Osswald H. Stimulus-dependent inhibition of platelet aggregation by the protein kinase $\mathrm{C}$ nhibitors polymyxin B, H-7 and staurosporine. Biochem Biophys Res Commun 1988;151:542-7.

23 Takahashi I, Kobayashi E, Nakano H, et al. Potent selective inhibition of 7-O-methyl UCN-01 against protein kinase C. I Pharmacol Exp Ther 1990;255:1218-21.

24 Tischler AS, Ruzicka LA, Perlman RL. Mimicry and inhibition of nerve growth factor effects: interactions of staurosporine, forskolin, and K252a in PC12 cells and normal rat chromaffin cells in vitro. $\mathcal{F}$ Neurochem 1990;55: mal rat che-65.

25 Tamaoki T, Nomoto H, Takahashi I, et al. Staurosporine, a potent inhibitor of phospholipid/ $/ \mathrm{Ca}^{++}$dependent protein kinase. Biochem Biophys Res Commun 1986;135:397-402. 
26 Tamaoki T. Use and specificity of staurosporine, UCN-01, and calphostin C as protein kinase inhibitors. Methods and calphostin C as pro

27 Yanagihara N, Tachikawa E, Izumi F, et al. Staurosporine: an effective inhibitor for $\mathrm{Ca}^{2+} / \mathrm{calmodulin}$-dependent protein kinase II. F Neurochem 1991;56:294-8.

28 Herbert JM, Augereau JM, Gleye J, et al. Chelerythrine is a potent and specific inhibitor of protein kinase C. Biochem Biophys Res Commun 1990;172:993-9.

29 Barg J, Belcheva MM, Coscia CJ. Evidence for the implication of phosphoinositol signal transduction in mu-opioid inhibition of DNA synthesis. F Neurochem 1992;59:114552.

30 Venema RC, Raynor RL, Noland TA Jr, et al. Role of protein kinase $\mathrm{C}$ in the phosphorylation of cardiac myosin light chain 2. Biochem 7 1993;294:401-6.

31 Mamiya N, Goldenring JR, Tsunoda Y, et al. Inhibition of acid secretion in gastric parietal cells by the $\mathrm{Ca}^{2+}$ calmodulin-dependent protein kinase II inhibitor KN-93.

32 Sugita Y, Nagao T, Urushidani T. Nonspecific effects of the pharmacological probes commonly used to analyze signal transduction in rabbit parietal cells. Eur f Pharmacol 1999, 365:77-89.

33 Hagiwara $\dot{M}$, Inagaki $M$, Hidaka $H$. Specific binding of a novel compound, $\mathrm{N}$-[2-(methylamino)ethyl]-5-isoquinolinesulfonamide $(\mathrm{H}-8)$ to the active site of cAMP dependent protein kinase. Mol Pharmacol 1987;31:523-8.

34 Hidaka $\mathrm{H}$, Inagaki $\mathrm{M}$, Kawamoto $\mathrm{S}$, et al. Isoquinolinesulfonamides, novel and potent inhibitors of cyclic nucleotide dependent protein kinase and protein kinase C. Biochemistry 1984;23:5036-41.

35 Heim HK, Ruoff HJ. Cyclic GMP and acid production in isolated gastric cells. Naunyn Schmiedebergs Arch Pharmacol 1985;330:147-54.

36 Brown JF, Hanson PJ, Whittle BJ. The nitric oxide donor, $\mathrm{S}$-nitroso-N-acety-penicillamine inhibits secretory activity in rat isolated parietal cells. Biochem Biophys Res Commun in rat isolated parie

37 Chijiwa $\mathrm{T}$, Mishima A, Hagiwara M, et al. Inhibition of forskolin-induced neurite outgrowth and protein phosphoforskolin-induced neurite outgrowth and protein phospho-
rylation by a newly synthesized selective inhibitor of cyclic rylation by a newly synthesized selective inhibitor of cyclic
AMP-dependent protein kinase, N-[2-(p-bromocinnAMP-dependent protein kinase, $\mathrm{N}$-[2-(p-bromocinnPC12D pheochromocytoma cells. F Biol Chem 1990;265:

38 Chiba T, Fisher SK, Agranoff BW, et al. Autoregulation of muscarinic and gastrin receptors on gastric parietal cells Am f Physiol 1989;256:G356-63.
39 Muramatsu S, Tani N, Miwa T, et al. Protein kinase C gene expression in dispersed guinea-pig gastric parietal cells. Digestion 1998;59:40-6.

40 McKenna P, Williams JM, Hanson PJ. Protein kinase C alpha is the isoform responsible for inhibition of histamine $\mathrm{H} 2$ receptor mediated stimulation of adenylate cyclase in the human gastric cancer cell line HGT-1. Biochem Soc Trans 1993;21:192S

41 Bonizzi G, Piette J, Schoonbroodt S, et al. Role of the protein kinase $\mathrm{C}$ lambda/iota isoform in nuclear factor-kappaB activation by interleukin-1beta or tumor necrosis factoralpha: cell type specificities. Biochem Pharmacol 1999;57: 713-20.

42 Varley CL, Brown BL, Groome N, et al. Interleukin-1betainduced expression of protein kinase $\mathrm{C}(\mathrm{PKC})$-delta and epsilon in NIH 3T3 cells. Cytokine 1997;9:577-81.

43 Brooks JW, Mizel SB. Interleukin-1 and signal transduction. Eur Cytokine Netw 1994;5:547-61.

44 Park J, Chiba T, Yamada T. Mechanisms for direct inhibition of canine gastric parietal cells by somatostatin. $\mathcal{F}$ Biol Chem 1987;262:14190-6.

45 Jarvis WD, Turner AJ, Povirk LF, et al. Induction of apoptotic DNA fragmentation and cell death in HL-60 human promyelocytic leukemia cells by pharmacological inhibitors of protein kinase C. Cancer Res 1994;54:170714.

46 Bruno S, Ardelt B, Skierski JS, et al. Different effects of staurosporine, an inhibitor of protein kinases, on the cell cycle and chromatin structure of normal and leukemic lymphocytes. Cancer Res 1992;52:470-3.

47 Saperas E, Cominelli F, Tache Y. Potent inhibition of gastric acid secretion by intravenous interleukin- 1 beta and -1 alpha in rats. Peptides 1992;13:221-6.

48 Beales I. H. pylori-associated hypochlorhydria. Gastroenterology 1998;114:618-20.

49 Yasunaga Y, Shinomura Y, Kanayama S, et al. Mucosal interleukin-1 beta production and acid secretion in enlarged fold gastritis. Aliment Pharmacol Ther 1997;11: 801-9.

50 Konturek PC, Brzozowski T, Konturek SJ, et al. Mouse model of Helicobacter pylori infection: studies of gastric function and ulcer healing. Aliment Pharmacol Ther 1999;13:333-46.

51 el Omar EM, Oien K, el Nujumi A, et al. Helicobacter pylori infection and chronic gastric acid hyposecretion. Gastroenterology 1997;113:15-24.

\section{1st Asia Pacific Forum on Quality Improvement in Health Care}

\section{Three day conference}

\section{Wednesday 19 to Friday 21 September 2001 Sydney, Australia}

We are delighted to announce this forthcoming conference in Sydney. Authors are invited to submit papers (call for papers closes on Friday 6 April), and delegate enquiries are welcome.

The themes of the Forum are:

- Improving patient safety

- Leadership for improvement

- Consumers driving change

- Building capacity for change: measurement, education and human resources

- The context: incentives and barriers for change

- Improving health systems

- The evidence and scientific basis for quality improvement.

Presented to you by the BMJ Publishing Group (London, UK) and Institute for Healthcare Improvement (Boston, USA), with the support of the the Commonwealth Department of Health and Aged Care (Australia), Safety and Quality Council (Australia), NSW Health (Australia), and Ministry of Health (New Zealand).

For more information contact: quality@bma.org.uk or fax +44 (0)20 73836869 